\title{
Phytochemical Evaluation and Antioxidant Properties of Three Medicinal Plants Extracts
}

\author{
Isaac John Umaru ${ }^{1,2 *}$, Fasihuddin $\mathrm{BA}^{1}$, 0 titoju $00^{2}$ and Hauwa $\mathrm{AU}^{3}$ \\ ${ }^{1}$ Faculty of Resource Science and Technology, Universiti of Malaysia Sarawak, Malaysia \\ 2Department of Biochemistry, Federal University Wukari Taraba State, Nigeria \\ ${ }^{3}$ Department of Biochemistry, Modibo Adama University of Technology Yola Adamawa \\ state, Nigeria
}

*Corresponding author: Isaac John Umaru, Faculty of Resource Science and Technology, Universiti of Malaysia Sarawak, Kota Samarahan Malaysia, Kuching, Malaysia, E-mail: umaruisaac@gmail.com

\section{Abstract}

Objective: Medicinal plant over the years has been used to treat many diseases such as Diabetic, cancer, tumour, ulcers and bacterial. This study aimed at conducting the phytochemical analysis and in vitro antioxidant activities of the stembark extracts of selected medicinal plants (Leptadenia hastata, Barringtonia asiatica and Barringtonia racemosa).

Material and Methods: All the plants were extracted by solvent maceration extraction methods. The Phytochemical analysis for alkaloids, phenolic compounds, tannins, flavonoids, coumarins, steroids, terpenoids, cardiac glycosides, essential oils, saponins and resins by using the standard methods. The in vitro antioxidant property was evaluated by assessing the DPPH'radical scavenging ability.

Results: The preliminary Phytochemical evaluation of these plant species exhibited that the Dichloromethane extracts of Leptadenia hastata, Barringtonia asiatica and Barringtonia racemosa (Stem-bark) contain alkaloids, Sterols, Phenols, Flavonoids, Essential oil, Tannins, Terpenoid, Carbon hydrate, Cardiac glycosides, Saponins, Proathocyanidins, Coumarins, with Sterol and essential oil absent in the Leptadenia hastata and Coumarin in the Barringtonia asiatica and Barringtonia racemosa. The in vitro antioxidant activity of the species of Leptadenia hastata, Barringtonia asiatica and Barringtonia racemosa from five solvent extract of stem-barks have prominent antioxidant activities.

Conclusion: This study suggests the potential source of natural antioxidant in Leptadenia hastata, Barringtonia asiatica and Barringtonia racemosa. Further research is highly recommended on the isolation of the bioactive compounds from these species and also to understand their mode of action in controlling various dreadful diseases.

Keywords: Phytochemical, Antioxidant, Leptadenia hastata, Barringtonia asiatica and Barringtonia racemosa 


\section{Medicinal \& Analytical Chemistry International Journal}

\section{Introduction}

The medicinal plants in form of roots, barks, leaves, seeds and fruits have been used to manage various illnesses since the ancient time. These plants are composed of some bioactive compounds influencing the physiological functions of the human body and these active phyto constituents include alkaloids, terpenes and phenolic compounds [1], biosynthesized by the pathways of acetyl coenzyme A, shikimic acid, mevalonic acid and 1deoxylulose 5-phosphate in the plant [2]. The Phytochemical is being broadly examined for its ability to provide health benefits, the underlying mechanism of which is due to their bioactivities as substrates for biochemical reactions, cofactors of enzymatic reactions, and inhibitors of enzymatic reactions [3].

Antioxidant free radical scavenging, free radicals or reactive oxygen species (ROS) are unstable intermediates formed from molecules via the breakage of a chemical bond such that each fragment keeps one electron, via a redox reaction [4]. The ROS are categorized into oxygencentered radicals and oxygen-centered non-radicals. The oxygen-centered radicals include superoxide anion $\left(\cdot \bullet_{2}^{-}\right)$, hydroxyl radical $(\bullet \mathrm{OH})$, alkoxyl radical $(\mathrm{RO} \bullet)$ and peroxyl radical (ROO•), and nitrogen species. The oxygencentered non-radicals are hydrogen peroxide $\left(\mathrm{H}_{2} \mathrm{O}_{2}\right)$ and singlet oxygen $\left(1 \mathrm{O}_{2}\right)$, hypochlorous acid $(\mathrm{HClO})$ and ozone $\left(\mathrm{O}_{3}\right)$ [5]. Free radicals are also generated either from normal essential metabolic processes in the human body or from external sources such as exposure to X-rays, ozone, cigarette smoking, air pollutants and industrial chemicals causing oxidative stress which is able to adversely alter lipids, protein and DNA triggering various human complications such as cancers, atherosclerosis, neurodegenerative diseases, diabetes, age-related eye disease and Parkinson's disease [6].

Thus, these free radicals include non-enzymatic and a series of antioxidant enzymes. The non-enzymatic constituents include glutathione, selenium, vitamin $\mathrm{C}$ and vitamin E. The antioxidant enzymes embrace glutathione peroxidase, catalase and superoxide dismutase which are the predominant antioxidant enzymes playing a key role in minimizing the oxidative stress [7]. Thus, Phytochemical is being broadly examined for its ability to provide health benefits, and several reports proved their curative effects on cardiovascular diseases, inflammation, cancers, diabetes and AIDS [8].

The medicinal plants of interest are Leptadenia hastata, Barringtonia asiatica and Barringtonia racemosaare widely distributed throughout the world. This plant species is used in various applications especially for medicinal purposes. They are significant element of the world cultural heritage; they resort for treating health problems. This knowledge is passed down from generation to the next generation with or without little written information was available on the active, safety and effectiveness of this medicine. They are distributed from Africa to Bangladesh, Sri Lanka, India, China, Taiwan, and Japan as well as Malaysia in Sarawak [9].

Leptadenia-hastata (Pers.) Decne is a perennial plant of the family of Asclepediacea, the plant is edible nondomesticated vegetable and it is collected in wild throughout Africa. It is a voluble herb with creeping latex stems, glabescent leaves, glomerulus and racemes flowers as well as follicle fruits as shown in Figure 1. The leaves are up to $10 \mathrm{~cm}$ long, mostly ovate and light green. The flowers are cream or yellowish green [9].

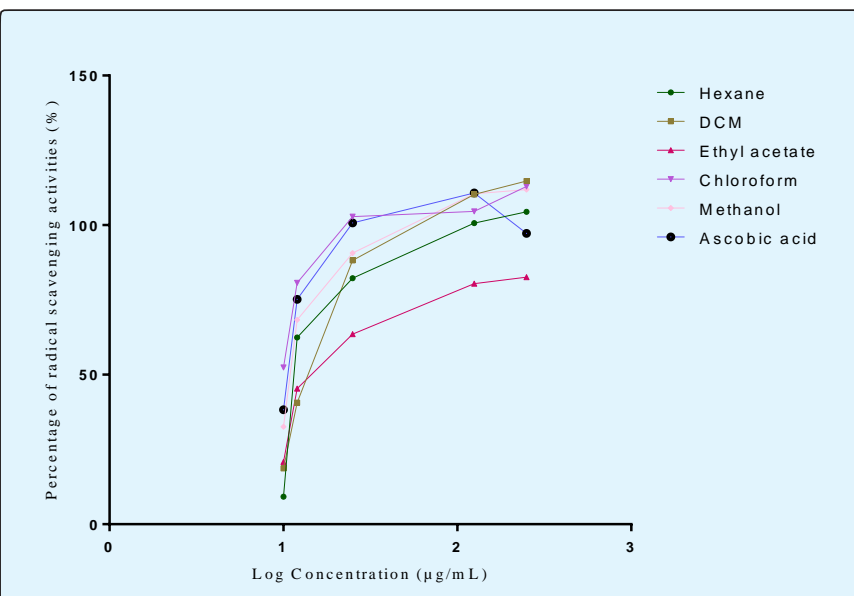

Figure 1: Graph: $\mathrm{IC}_{50}$ value of stem-bark of Leptadenia hastata.

It is typically grown in tropical dry lands in sandy soil. Wild foods like this plant provide food security during seasonal changes and are used medicinally in many areas. The plant belongs too many of the root-type famine-food plants; they are drought tolerant and can stay in the soil intact for a long time. Therefore, they can be collected when the need is greatest. Most of the leafy-type faminefood plants are locally referred to and classified as 'weeds', sprouting and flourishing after rains. There are two main periods of maximum consumption of the leaves and tender parts of such famine-food plants. The first period is while farmers are waiting for the upcoming crop 


\section{Medicinal \& Analytical Chemistry International Journal}

harvest and, the second main period is when they run out of food stocks from the previous harvest, and are hence facing a food shortage. People try, whenever possible to add famine-food to local staple foods or to mix it with other foodstuff to mask the often-offensive nature of the food and to reduce any characteristic and unpleasant side effects. At present approximately 50 wild-foods plant species are listed and classified as typical famine-food plants of which Leptadenia hastata [9].

Barringtonia asiatica is a species of Barringtonia native to mangrove habitats on the tropical, it is a common plant in the Malaysian Mangroves and wetlands such as the Kuching wetlands Sarawak and Bako National Park, and it is also found in tropical Africa, Nigeria and Madagascar. Its large pinkish-white, pompon flowers give off a sickly-sweet smell to attract bats and moths which pollinate the flowers at night. It is grown along streets for decorative and shade purposes in some parts of Sarawakian houses and it's also known as Box Fruit due to the distinct box-shaped of the fruit, it is a medium-sized tree growing to $7-25 \mathrm{~m}$ tall $[10,11]$.

Barringtonia racemosa (L) Which is also known as Putat, fish poison tree or powder puff tree is a type of highly valuable plant species due to its medicinal values. Geographically it is found to be widely distributed from eastern Africa and Madagascar to Micronesian and Polynesian Island as well as in mangrove river site of Sarawak, this species was collected at the Meranak river bank in kota-samarahan, sarawak. The plant has been associated very well in various tribes around the world with diverse ethno-botanical uses [12]. The mangrove tree is easily recognized by its large leaves, delicate white flowers and guava-like fruit that hang in long racemes. It has a straight, unbranched stem that leads to a rounded crown and is usually $4-8 \mathrm{~m}$ tall, but occasionally reaches $15 \mathrm{~m}$. The bark is greyish brown to pink with white blotches and raised dots and lines. The branches are marked with leaf scars. This species is classified as underutilized crops [13].

However, no much scientific authentication has been made for most of these medicinal plants thus, the present study was carried out for the Phytochemical analysis of the dichloromethane extract and in vitro antioxidant activities of the stem-bark of Leptadenia hastata, Barringtonia asiatica and Barringtonia racemosa for hexane, dichloromethane, ethyl acetate, chloroform and methanol extracts. As such this preliminary study draws attention to the need for further studies of the active secondary metabolites identified in the reported species for the treatment of many diseases as well as to understand their mode of action in controlling various dreadful diseases.

\section{Materials and Methods}

\section{Preparation of Samples}

Fresh leaves of the plant Leptadenia hastata was washed with distilled water to remove the soil and dust particles, they are thoroughly air dried and powdered using laboratory grinder machine (FGR-350, Quest Scientific). Extraction using hexane by placing $150 \mathrm{~g}$ of the powdered samples into an Erlenmeyer flask and hexane three times the weight of the extracts was added, the solution was covered and shaken at an interval of an hour and then allowed at room temperature to stand for 7 days. The mixture was then filtered using Whatman filter paper No.4 the residue was re-extracted with fresh hexane for another $72 \mathrm{~h}$ and filtered. Both extracts were combined and concentrated with a rotary evaporator (Heidolph Laborota 4000 efficient) under reduced pressure to obtain the hexane crude extract. The residues were reextracted using a similar procedure with dichloromethane $\left(\mathrm{CH}_{2} \mathrm{CLl}_{2}\right)$, followed by ethyl acetate $\left(\mathrm{C}_{2} \mathrm{H}_{5} \mathrm{COOH}\right)$, chloroform $\left(\mathrm{CHCL}_{3}\right)$, and methanol $(\mathrm{MeOH})$ to obtain dichloromethane, ethyl acetate, chloroform and crude extracts, respectively. The dry weight and yield of each crude extracts were determined. It was then stored under a frozen condition until required.

The dichloromethane extracts of Leptadenia hastata, Barringtonia asiatica and Barringtonia racemosa stembarks underwent the Phytochemical screening in order to detect the presence or the absence of alkaloids, phenolic compounds, tannins, flavonoids, coumarins, steroids, terpenoids, cardiac glycosides, essential oils, saponins Carbohydrate and resins by using the standard methods [13]. While the Hexane, dichloromethane, ethyl acetate, chloroform and methanol extract underwent the antioxidant evaluation [14].

As reported by Umaru, et al. [15] Reagent preparation for Phytochemical Analysis: $1 \%$ ammonia: $1 \mathrm{ml}$ of ammonia dissolved in $99 \mathrm{ml}$ of distilled water. $1 \%$ ammonium chloride: $1 \mathrm{~g}$ of ammonium chloride was dissolved in $100 \mathrm{ml}$ distilled water. Mayer's reagent: It is used for the detection of alkaloids. Solution (a) 1.36g of mercuric chloride is dissolved in $60 \mathrm{ml}$ of distilled water. (b) $5 \mathrm{~g}$ of potassium iodide is dissolved in $20 \mathrm{ml}$ of distilled water. Solution (a) and (b) are mixed and the volume was adjusted to $100 \mathrm{ml}$ with distilled water. 


\section{Medicinal \& Analytical Chemistry International Journal}

Wagner's Reagent: It is a general reagent for the detection of alkaloids. $1.27 \mathrm{~g}$ of iodine and $2 \mathrm{~g}$ of potassium iodide was dissolve in $5 \mathrm{ml}$ of water and the volume was made $100 \mathrm{ml}$ with distilled water.

Fehling's Solution: It is used for the detection of reducing sugars. 34.66g of copper sulphate is dissolved in distilled water and the volume was made to $500 \mathrm{ml}$ (Solution-a). $173 \mathrm{~g}$ of potassium sodium tartrate and $50 \mathrm{~g}$ of sodium hydroxide in $\mathrm{D} / \mathrm{W}$ was dissolved and volume was made up to $500 \mathrm{ml}$ (solution -b). The two solutions were mixed in equal volume for prior use.

Ferric Chloride (Alcoholic): A $5 \% \mathrm{w} / \mathrm{v}$ solution of ferric chloride in $90 \%$ alcohol is used for the detection of phenols.

Lead Acetate: A 25\% basic lead acetate solution is used for the detection of flavonoid.

\section{Tests for Phytochemical Screening}

Test for Sterols: Two tests were used the Salkowski test and Liebermann-Burchard test. The test didn't give positive result confirming the absence of Sterols. The salkowski test: In $2 \mathrm{ml}$ of plant extract, $2 \mathrm{ml}$ of chloroform and $2 \mathrm{ml}$ of concentrated $\mathrm{H}_{2} \mathrm{SO}_{4}$ was added and shaken well. Chloroform layer didn't appear red and acid layer greenish yellow fluorescent. Thus sterols were absent. However, the Liebermann-Burchard Test: $2 \mathrm{ml}$ of the extract was mixed with chloroform. 1-2ml acetic anhydride and 2 drops of concentrated $\mathrm{H}_{2} \mathrm{SO}_{4}$ from the side of the test tube was added in the mixture. The red, blue and finally green colour was not observed indicates the presence of sterols.

Test for Terpenoids: This was determined by Salkowski test which gave a positive result thus confirms the presence of Terpenoids. The extract was also mixed with $2 \mathrm{ml}$ of chloroform and concentrated $\mathrm{H}_{2} \mathrm{SO}_{4}(3 \mathrm{ml})$ is carefully added by through the side to form a layer. A reddish brown coloration of the interface was formed which confirm positive result of the presence of terpenoids.

Test for Alkaloids: Mayer's reagent \& Wagner's reagent was used to confirm the presence of Alkaloids in the extract. The Methanol plant extract was warmed with $2 \%$ $\mathrm{H}_{2} \mathrm{SO}_{4}$ for two minutes. It is filtered and few drops of reagents were added separately.

a) Mayer's reagent: A creamy- white coloured precipitation appeared giving a positive result.

b) Wagner's reagent: Gave a reddish-brown precipitate which confirms the presence of alkaloids in the extract.

Test for Carbohydrates: In determining the presence of carbohydrate, Molisch test and Fehling's test was used. a) Molisch Test: Extract was treated with few drops of alcoholic alpha-naphthol and $0.2 \mathrm{ml}$ of concentrated sulphuric acid was added slowly along the sides of test tube, purple to violet colour ring was observed at the junction.

b)Fehling's Test: The Fehling A and Fehling B reagents were mixed and few drops of extract were added and boiled. A brick red coloured precipitate of cuprous oxide forms was observed thus confirms the presence of carbohydrates.

Test for Flavonoids: In the test for Flavonoid in this extract Ammonium Test and Aluminium Chloride Test did confirm the presence of flavonoids in the Hexane extract. A small quantity of the extract is heated with $10 \mathrm{ml}$ of ethyl acetate in boiling water for three minutes. The mixture is filtered and the filtrates are used for the following test.

a) Ammonium Test: The filtrate was shaken with $1 \mathrm{ml}$ of dilute ammonia solution (1\%). The layers were allowed to separate. A yellow coloration was observed at ammonia layer which indicates the presence of the flavonoid from the plant extract.

b)Aluminium Chloride Test: The filtrates were shaken with $1 \mathrm{ml}$ of $1 \%$ aluminium chloride solution and a light yellow colour did appear indicating the presence of flavonoids. The light yellow colour indicates the presence of flavonoid and when dilute $\mathrm{NaOH}$ and $\mathrm{HCl}$ is added the yellow solution turns colorless.

Test for Tannins: Ferric Chloride Test and Lead Sub Acetate Test is test to confirm the presence of Tannins in the plant extract. A small quantity of the extract is boiled with $5 \mathrm{ml}$ of $45 \%$ solution of ethanol for 5 minutes. Each of the mixture was cooled and filtered. The different filtrates were used for the following tests

a) Ferric Chloride Test: $1 \mathrm{ml}$ each of filtrate is diluted with distilled water and two drops of ferric chloride is added. A transient greenish to black colour indicated the presence of Tannins.

b) Lead Sub Acetate Test: $1 \mathrm{ml}$ of the different filtrate was added with three drops of lead sub acetate solution. A creamy gelatinous precipitation indicates positive test for Tannins.

Test for Phenols: Phenols was present in the hexane extract. Ellagic Acid Test: The test solution was treated with few drops of $5 \%(\mathrm{w} / \mathrm{v})$ glacial acetic acid and $5 \%$ (w/v) $\mathrm{NaNO}_{2}$ solution. The solution did turn muddy with Niger brown precipitate occurred. Hence, the presence of phenols was confirmed.

Test for Glycosides: The Keller-Kiliani Test and Concentrate $\mathrm{H}_{2} \mathrm{SO}_{4}$ Test were used to confirm the presence of Glycosides in the hexane extract. KellerKiliani Test: In $2 \mathrm{ml}$ of the plant extract, glacial acetic acid, 


\section{Medicinal \& Analytical Chemistry International Journal}

one drop of $5 \% \mathrm{FeCl}_{3}$ and conc. $\mathrm{H}_{2} \mathrm{SO}_{4}$ were added. Reddish brown colour appears at junction of the two liquid layers and upper layer appears bluish green, confirming the presence of glycosides. However, in Conk $\mathrm{H}_{2} \mathrm{SO}_{4}$ Test: In $5 \mathrm{ml}$ plant extract, $2 \mathrm{ml}$ glacial acetic acid, one drop of $5 \% \mathrm{FeCl}_{3}$ and Conc. $\mathrm{H}_{2} \mathrm{SO}_{4}$ were added. Brown ring appears, indicating the presence of glycosides.

Test for Saponin: Foam test and haemolytic test were conducted which gave a negative result. Foam Test: The extract was diluted with $20 \mathrm{ml}$ of distilled water and it was shaken in a graduated cylinder for 15 minutes. A layer of foam was not formed which indicated the absence of Saponin. In the haemolysis Tests: - Hexane extract was added to one drop of blood placed on a glass slide. Haemolytic zone did not appear. The test confirms that Saponin is absent in the extract.

Test for Coumarins (NaOH Test): The crude extracts with the addition of ethanol in the concentration of $100 \mathrm{mg} / 10 \mathrm{~mL}$ were filtrated. The two-milliliter of filtrate was loaded into the test tube and added with $3 \mathrm{~mL}$ of $10 \%-\mathrm{NaOH}$. The yellow coloration represented the presence of Coumarins.

Test for Essential Oils (NaOH-HCl Test): In the test tube, the filtrate $2 \mathrm{~mL}$ of the extract was added with $100 \mu \mathrm{l}$ of $1 \mathrm{M}-\mathrm{NaOH}$, followed by the addition of 3 drops of $1 \mathrm{M}$ $\mathrm{HCl}$. The mixture was shaken. The white precipitate demonstrated the presence of Essential Oils.

Test for Resins (Turbidity Test): Ten milliliter of distilled water were added to $200 \mathrm{mg}$ of the crude extract and filtered into the test tube, and the mixture was observed. The occurrence of turbidity showed the presence of Resins.

\section{DPPH (2, 2-diphenyl-1-pycryl-hydrazyl) Free Radical Scavenging Assay}

The antioxidant test for this plants species through (DPPH) radical scavenging assay 1,1-diphenyl-2picrylhydrazyl, a radical scavenging method which is a rapid and sensitive procedure to observe the antioxidant activity of plant extracts. The sample was prepared by diluting $6 \mathrm{mg}$ of crude extract into $6 \mathrm{~mL}$ of methanol, producing a concentration of $1000 \mu \mathrm{g} / \mathrm{mL}$. The stock solution was sonicated to ensure the homogeneity of the sample five other concentrations were prepared at 10,50 , 100,500 and $1000 \mu \mathrm{g} / \mathrm{mL}$, diluted from the $1000 \mu \mathrm{g} / \mathrm{mL}$ stock solution. Sample of $5000 \mu \mathrm{g} / \mathrm{mL}$ was prepared separately by diluting $25 \mathrm{mg}$ of crude extract into $5 \mathrm{~mL}$ of methanol. Approximately $3 \mathrm{~mL}$ of $0.1 \mathrm{mM}$ solution of 2,2 diphenyl-1-pycrylhydrazyl (DPPH) in methanol was each added into six series of prepared concentrations $(10,50$, $100,500,1000$ and $5000 \mu \mathrm{g} / \mathrm{mL}$ ) of sample solutions
$(1 \mathrm{~mL})$. Analysis was done in triplicate. The solution was mixed vigorously and left to stand at room temperature for 30 minutes in the dark after which its absorbance was measured spectrophotometrically at $517 \mathrm{~nm}$ using Jasco ultra violet spectrophotometer model V-630. Methanol was used as blank (only methanol) and negative control (1mL methanol mixed with $3 \mathrm{~mL}$ DPPH), while ascorbic acid (vitamin C) as the standard. The concentration of the sample required to inhibit $50 \%$ of the DPPH free radical was calculated as $\mathrm{IC}_{50}$ and the value was determined using Log dose inhibition curve which performed by using PRISM version 3.02 software, based on the calculated values of the DPPH scavenging activity (\%) of the sample [15].

DPPH scavenging activity (\%) was calculated with formula $=\mathrm{A} 0-\mathrm{A} 1 / \mathrm{A} 0 \times 100$, where $\mathrm{A} 0$ was the absorbance of the control, while A1 was the absorbance in presence of the sample.

\section{Result and Discussion}

The result of phytochemical screening of these medicinal plants of dichloromethane stem-bark extract Indicated the presence of most of the phytochemical in the Leptadenia hastata, Barringtonia asiatica and Barringtonia racemosa with the absence of sterol and resin in Leptadenia hastata, as while as Barringtonia asiatica and Barringtonia racemosa having both the absence of coumarin and little amount of sterol and tannin. The study on the stem-bark extract of Leptadenia hastata Barringtonia asiatica and Barringtonia racemosa revealed that this plant contains a substantial amount of bioactive compound such as phenols which was linked with antioxidant activity of plants [16]. Thus, it was believed to have improved health and nutrition through the consumption of this herb of such plants [17]. Reasonable amount of these phytochemicals observed in this study, is an indication of the potential of Leptadenia hastata, Barringtonia asiatica and Barringtonia racemosa in the management of diseases related to the accumulation of free radicals in the body including diabetes mellitus, antitumor, anti-mutagenic and antifungal, antibacterial potentials. Thus, the antioxidant activity of the plants extracts, the results are shown as the relative activities against the standard ascorbic acid. The results showed that for the dichloromethane extracts of the three medicinal plant extracts tested it was observed to have a remarkable antioxidant activity of the stem-bark extract with $\mathrm{DPPH}$ inhibition of $\mathrm{IC}_{50}$ for Leptadenia hastata, Barringtonia asiatica and Barringtonia racemosa to be very significant sometime higher than the control in 


\section{Medicinal \& Analytical Chemistry International Journal}

some instance of the plant extract, depending on the solvent extract. Higher antioxidant was displayed $\mathrm{IC}_{50}$ value from the chloroform extract Leptadenia hastata $85.51 \mu \mathrm{g} / \mathrm{mL}$ compared to the chloroform extract of Barringtonia asiatica and Barringtonia racemosa with $21.33 \mu \mathrm{g} / \mathrm{mL}$ and $19.09 \mu \mathrm{g} / \mathrm{mL}$ respectively. Thus, the presence of Leptadenia hastata, Barringtonia asiatica and
Barringtonia racemosa stem-bark extract with potent antioxidant as shown in Tables 1-4 and Figures 2 \& 3 continues to be of great importance in the search for remedies against free radical-mediated diseases as well as prevention of oxidative reactions in foods, protection against DNA damage, anti-bacterial, and anti-fungal properties.

\begin{tabular}{|c|c|c|c|c|}
\hline Phytochemicals & Types of test & Leptadenia hastata & Barringtonia asiatica & $\begin{array}{c}\text { Barringtonia } \\
\text { racemosa }\end{array}$ \\
\hline Sterols & $\begin{array}{c}\text { Salkowski and Liebermann- } \\
\text { Burchard }\end{array}$ & - & + & + \\
\hline Phenols & Ellagic acid & +++ & +++ & +++ \\
\hline Flavonoids & $\begin{array}{c}\text { Ammonium and Aluminium } \\
\text { chloride }\end{array}$ & ++ & ++ & + \\
\hline Essential oil & NaOH- HCL & + & ++ & ++ \\
\hline Tannins & $\begin{array}{c}\text { Ferric chloride and Lead Sub } \\
\text { acetate }\end{array}$ & ++ & ++ & + \\
\hline Terpenoid & Salkowski & ++ & + & ++ \\
\hline Carbonhydrate & Molisch and Fehling's & ++ & ++ \\
\hline Cardiac glycosides & Keller-killiani and $\mathrm{H}_{2} \mathrm{SO}_{4}$ & ++ & ++ & ++ \\
\hline Saponins & Foam and Haemolytic & + & ++ & + \\
\hline Resins & Turbidity Test & - & - & ++ \\
\hline Coumarins & NaOH & + & ++ & ++ \\
\hline Alkaloid & $\begin{array}{c}\text { Dragendorff's, Mayer's and } \\
\text { Wagner's Tests }\end{array}$ & ++ & + & + \\
\hline
\end{tabular}

Table 1: Phytochemical screening of the Dichloromethane Stem-bark extracts of Leptadenia hastata, Barringtonia asiatica and Barringtonia racemosa.

$(+++)$ Very strongly Present, (++) Strongly present, (+) Weakly Present, (-) Absent

\begin{tabular}{|c|c|c|c|c|c|}
\hline Plant parts & Crude Extracts & Calibration equation & $\mathbf{R}^{\mathbf{2}}$ & $\mathbf{I C}_{\mathbf{5 0}}(\boldsymbol{\mu g} / \mathbf{m L})$ & $\mathbf{L o g}_{\mathbf{I C}} \mathbf{5 0}$ \\
\hline Stem-bark & Control & $3.629 \mathrm{x}+0.04310$ & 0.9657 & 61.96 & 1.792 \\
\hline & Hexane & $4.578 \mathrm{x}-0.03178$ & 0.9705 & 47.51 & 1.667 \\
\hline & DCM & $6.600 \mathrm{x}+0.03404$ & 0.9836 & 82.51 & 1.916 \\
\hline & Ethylacetate & $6.522 \mathrm{x}-0.02340$ & 0.9772 & 77.79 & 1.891 \\
\hline & Chloroform & $6.197 \mathrm{x}-0.02939$ & 0.9991 & 85.51 & 1.932 \\
\hline & Methanol & $2.701 \mathrm{x}+0.03013$ & 0.9798 & 28.55 & 1.456 \\
\hline
\end{tabular}

Table 2: $\mathrm{IC}_{50}$ value of Stem-bark of Leptadenia hastata.

\begin{tabular}{|c|c|c|c|c|c|}
\hline Plant parts & Crude Extracts & Calibration equation & $\mathbf{R}^{\mathbf{2}}$ & $\mathbf{I C}_{\mathbf{5 0}}(\boldsymbol{\mu g} / \mathbf{m L})$ & $\mathbf{L o g}_{\mathbf{I C}} \mathbf{5 0}_{\mathbf{5}}$ \\
\hline Stem-bark & Control & $23.14 \mathrm{x}-2.755$ & 0.9659 & 10.66 & 1.208 \\
\hline & Hexane & $1.172 \mathrm{x}+0.5623$ & 0.9605 & 74.02 & 1.054 \\
\hline & DCM & $7.451 \mathrm{x}+2.523$ & 0.7167 & 11.31 & 1.053 \\
\hline & Ethylacetate & $3.507 \mathrm{x}+2.464$ & 0.9959 & 18.73 & 1.272 \\
\hline & Chloroform & $2.798 \mathrm{x}-1.006$ & 0.9062 & 21.33 & 1.329 \\
\hline & Methanol & $22.09 \mathrm{x}-10.66$ & 0.9753 & 10.22 & 1.009 \\
\hline
\end{tabular}

Table 3: $\mathrm{IC}_{50}$ value of Stem-bark of Barringtonia asiatica Crude extract. 


\section{Medicinal \& Analytical Chemistry International Journal}

\begin{tabular}{|c|c|c|c|c|c|}
\hline Plant parts & Crude Extracts & Calibration equation & $\mathbf{R}^{\mathbf{2}}$ & $\mathbf{I C}_{\mathbf{5 0}}(\boldsymbol{\mu g} / \mathbf{m L})$ & $\mathbf{L o g}_{\mathbf{~ I C}} \mathbf{5 0}$ \\
\hline Stem-bark & Control & $23.14 \mathrm{x}+0.9356$ & 0.9367 & 10.66 & 1.028 \\
\hline & Hexane & $3.046 \mathrm{x}+0.9450$ & 0.866 & 16.11 & 1.207 \\
\hline & DCM & $7.993 \mathrm{x}+0.9418$ & 0.8415 & 11.32 & 1.054 \\
\hline & Ethylacetate & $3.867 \mathrm{x}+1.116$ & 0.9754 & 17.76 & 1.249 \\
\hline & Chloroform & $1.210 \mathrm{x}+1.042$ & 0.938 & 19.09 & 1.281 \\
\hline & Methanol & $22.09 \mathrm{x}+0.9912$ & 0.9753 & 10.22 & 1.009 \\
\hline
\end{tabular}

Table 4: IC 50 value of Stem-bark of Barringtonia racemosa Crude extract.

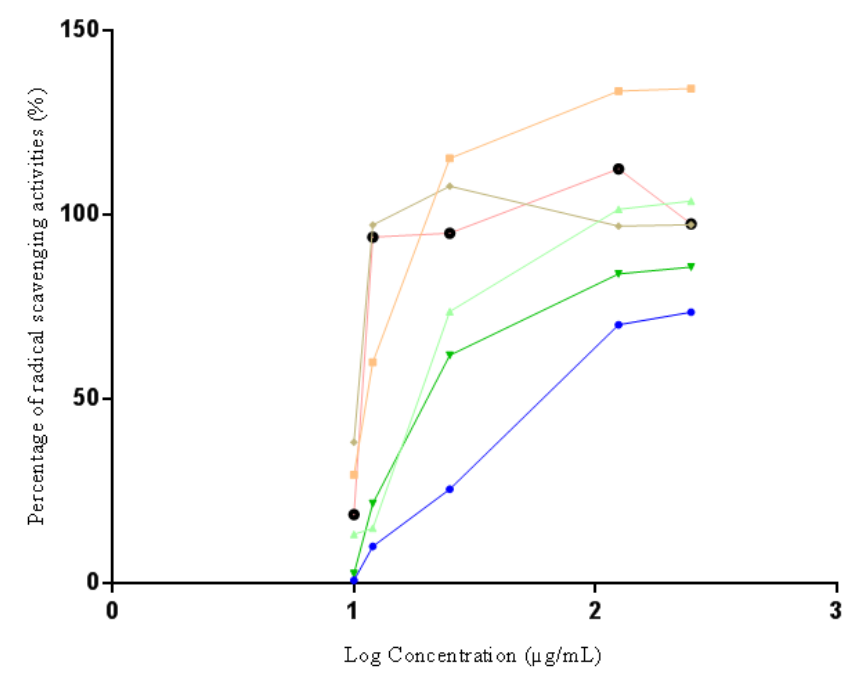

- Hexane

- DCM

Ethyl acetate

- Chloroform

- Methanol

- Ascobic acid

Figure 2: Graph: $\mathrm{IC}_{50}$ value of Stem-bark Crude extract of Barringtonia asiatica.

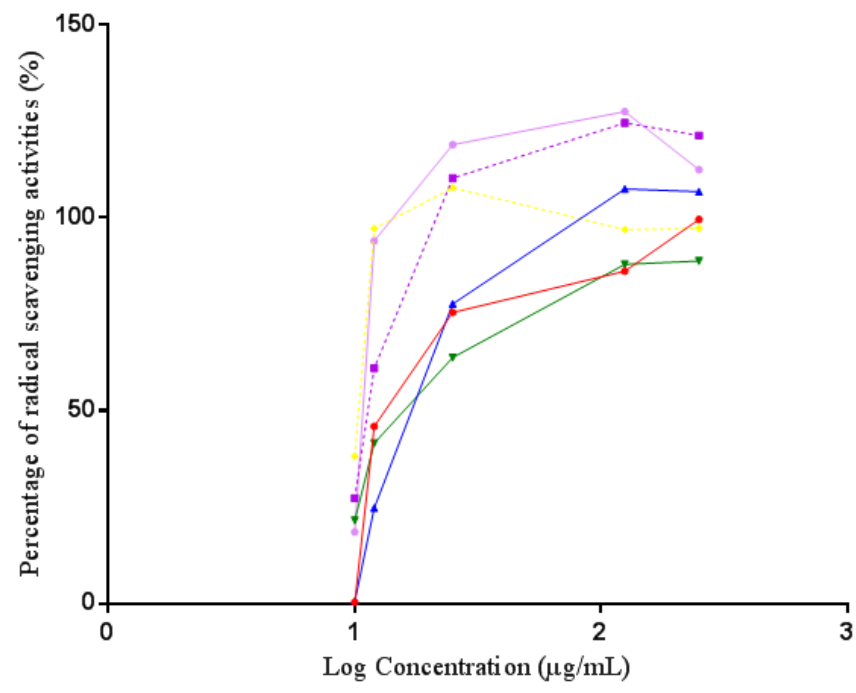

- Hexane

-. DCM

$\rightarrow$ Ethyl acetate

$\rightarrow$ Chloroform

Methanol

- Ascobic acid

Figure 3: Graph: $\mathrm{IC}_{50}$ value of Stem-bark Crude extract of Barringtonia racemosa. 


\section{Medicinal \& Analytical Chemistry International Journal}

\section{Conclusion}

The preliminary phytochemical test of these species exhibited that the dichloromethane extracts of Leptadenia hastata, Barringtonia asiatica and Barringtonia racemosa (stem-barks) contain alkaloids, phenolic compounds, tannins, flavonoids, terpenoids, cardiac glycosides, saponins and resins. Moreover, the in vitro antioxidant activity of the species Leptadenia hastata, Barringtonia asiatica and Barringtonia racemosa stem-barks have prominent antioxidant activities. This study suggests the potential source of natural antioxidant was observed in those medicinal plants. Further research is highly recommended on the isolation and characterization of the bioactive component from these species.

\section{Acknowledgment}

The author acknowledged the contribution of colleague and all supports from the Natural product laboratory FRST/ FSTS Universiti Malaysia Sarawak.

\section{References}

1. Kennedy DO, Wightman EL (2011) Herbal extracts and Phytochemical: plant secondary metabolites and the enhancement of human brain function. Advances in Nutrition 2(1): 32-50.

2. Kabera JN, Semana E, Mussa AR, He X (2014) Plant secondary metabolites: biosynthesis, classification, function and pharmacological properties. Journal of Pharmacy and Pharmacology 2(7): 377-392.

3. Dillard CJ, German JB (2000) Phytochemicals: nutraceuticals and human health. Journal of the Science of Food and Agriculture 80(12): 1744- 1756.

4. Pham Huy LA, He H, Pham Huy C (2008) Free radicals, antioxidants in disease and health. International Journal of Biomedical Science 4(2): 89- 96.

5. Sisein EA (2014) Biochemistry of free radicals and antioxidants. Scholars Academic Journal of Biosciences 2(2): 110-118.

6. Lobo V, Patil A, Phatak A, Chandra N (2010) Free radicals, antioxidants and functional foods: impact on human health. Pharmacognosy Review 4(8): 118-126.

7. El Bahr SM (2013) Biochemistry of free radicals and oxidative stress. Science International 1(5): 111-117.
8. Saxena M, Saxena J, Nema R, Singh D, Gupta A (2013) Photochemistry of medicinal plants. Journal of Pharmacognosy and Phytochemistry 1(6): 168-182.

9. Isaac JU, Fasihuddin BA, Hauwa AU, Kerenhappuch IU (2018) Leptadenia hastata (Pers) Decne: Phytochemical, Pharmacological, Biotechnological, Botanical, Traditional use and Agronomical Aspects. European Journal of Pharmaceutical and Medical Research 5(6): 109-119.

10. Thiel M, Gutow L (2005) The ecology of rafting in the marine environment. I. The floating substrata. Oceanography and Marine Biology: an annual review 42: 181-264.

11. Tsou CH, Mori SA (2002) Seed coat anatomy and its relationship to seed dispersal in subfamily Lecythidoideae of the Lecythidaceae (the Brazil nut family). Botanical Bulletin of Academia Sinica 43: 3756.

12. Osman NI, Sidik NJ, Awal A (2015) Pharmacological activities of Barringtonia racemosa L. (Putat), a tropical medicinal plant species. Journal of Pharmaceutical Sciences and Research 7(4): 185-188.

13. Isaac JU, Fasihuddin BA, Hauwa AU, Kerenhappuch IU (2018) Barringtonia racemosa: Phytochemical, Pharmacological, Biotechnological, Botanical, Traditional use and Agronomical Aspects. World Journal of Pharmacy and Pharmaceutical Science Research 7(8): 78-121.

14. Harborne JB (1984) phytochemical methods: a guide to modern techniques of plant analysis. Chapman and Hall Ltd, London.

15. Isaac JU, Fasihuddin AB, Hauwa $A U$ (2018) Phytochemical, Antifungal and Antibacterial potential of Leptadenia hastata stem-bark extract. MOJ Toxicology 4(4): 263-268.

16. Isaac JU, Fasihuddin AB, Hauwa AU (2018) Antioxidant properties and Antibacterial potential of Leptadenia hastata leaves extract on Staphylococcus Aureus. Drug Designing \& Intellectual Properties International Journal 1(5): 1-5.

17. Sakanaka S, Tachibana Y, Okada Y (2005) Preparation and antioxidant properties of extracts of Japanese persimmon leaf tea (kakinoha-cha). Food chemistry 89(4): 569-575. 